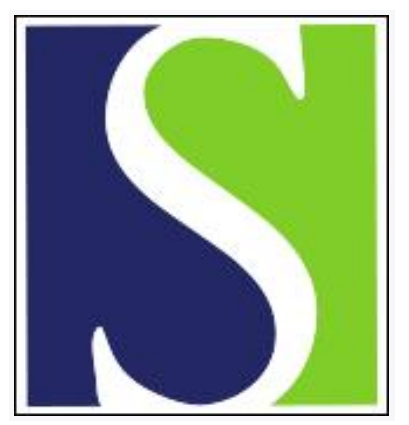

Scand J Work Environ Health 2008;34(4):278-287

https://doi.org/10.5271/sjweh.1272

Issue date: Aug 2008

Inflammation but no DNA (deoxyribonucleic acid) damage in mice exposed to airborne dust from a biofuel plant

by Madsen AM, Saber AT, Nordly P, Sharma AK, Wallin H, Vogel U

Affiliation: National Research Centre for the Working Environment, Lersø Parkallé, 105 DK-2100 Copenhagen, Denmark. amm@nrcwe.dk

Key terms: actinomycetes; airborne dust; asthma; beta-glucan; biofuel plant; cancer; combustion particle; deoxyribonucleic acid; DNA; DNA damage; endotoxin; genotoxicity; inflammation; mold; mouse; occupational exposure; respirable dust

This article in PubMed: www.ncbi.nlm.nih.gov/pubmed/18820821 


\title{
Inflammation but no DNA (deoxyribonucleic acid) damage in mice exposed to airborne dust from a biofuel plant
}

\author{
by Anne Mette Madsen, PhD, ${ }^{1}$ Anne Thoustrup Saber, PhD, ${ }^{1}$ Pernille Nordly, MSc, ${ }^{1}$ Anoop Kumar Shar- \\ ma, PhD, ${ }^{2}$ Håkan Wallin, PhD, ${ }^{1,3}$ Ulla Vogel, PhD 2,4
}

\begin{abstract}
Madsen AM, Saber AT, Nordly P, Sharma AK, Wallin H, Vogel U. Inflammation but no DNA (deoxyribonucleic acid) damage in mice exposed to airborne dust from a biofuel plant. Scand J Work Environ Health 2008;34(4):278287.

Objectives Particles in ambient air are associated with such health effects as lung diseases and cancer of the lung. Exposure to bioaerosols has been found to be associated with respiratory symptoms. The toxic properties of exposure to combustion and bioaerosol particles from biofuel plants have not been studied in detail. This study investigated whether exposure to dust from biofuel plants induces DNA (deoxyribonucleic acid) damage and inflammation in exposed mice.

Methods DNA damage and inflammation were evaluated in mice exposed through the intratracheal installation of airborne dust collected at a biofuel plant at the straw storage hall and in the boiler room. The mice were given either a single dose of dust ( 18 or $54 \mu \mathrm{g}$ ) or four doses of $54 \mu \mathrm{g}$ on each of four consecutive days. Control mice were exposed to a $0.9 \%$ sodium chloride solution.

Results In the mice exposed to $4 \times 54 \mu \mathrm{g}$ of dust, the lung tissue mRNA (messenger ribonucleic acid) levels of interleukin-6 (IL-6), monocyte chemoattractant protein-1 (MCP-1), and macrophage inflammatory protein-2 (MIP-2) were increased more than 10-fold if the dust was from the boiler room and 30- to 60-fold if the dust came from the straw storage hall. The levels of DNA strand breaks in broncheoalveolar lavage (BAL) cells from the mice exposed to dust did not differ from those in the control samples.

Conclusions The results indicate that the instillation of dust from a biofuel plant, at doses corresponding to 2 weeks of exposure to human endotoxins, results in a strong inflammatory response without detectable DNA damage in BAL cells. The dust from the straw storage hall induced the strongest inflammatory response and had the highest concentration of most microbial components.
\end{abstract}

Key terms actinomycetes; asthma; cancer; combustion particles; endotoxin; genotoxicity; beta-glucan, mold; occupational exposure; respirable dust.

Biofuel represents an important sustainable energy resource; however, the health effects of occupational exposure in biofuel plants have not been examined extensively. The most important biofuels are straw and wood chips. It has been reported that exposure to bioaerosols is high in biofuel plants (1), and, during combustion, fine and ultrafine particles are generated (2). Thus it has been shown that the suggested occupational exposure limits for microorganisms and endotoxins are exceeded for some worktasks in biofuel plants (1). The microbial composition of biofuel dust is determined by the kind of biofuel material handled (3), and the microbial exposure level in straw storage halls is influenced by the season of the year (1). Furthermore, the storage of biofuels outdoors over the summer increases microbial dustiness (4).

Exposure to microorganisms and endotoxin in dust from hay, straw, and grain has been found to be associated with health problems, including eye problems and various respiratory symptoms (5-7). The components of such dust have also been found to be related to health effects. For example, exposure to $\beta$-glucan in wood dust has been found to be related to reduced lung function (8), and exposure to cellulase in flour dust has been shown to be associated to occupational asthma (9). Exposure to particulate air pollution has been found to be associated with increased mortality and morbidity due

1 National Research Centre for the Working Environment, Copenhagen, Denmark.

2 National Food Institute, Technical University of Denmark, Søborg, Denmark.

3 Department of Environmental and Occupational Health, University of Copenhagen, Copenhagen Denmark.

4 Institute for Science, Systems, and Models, University of Roskilde, Roskilde, Denmark.

Correspondence to: Dr AM Madsen, National Research Centre for the Working Environment, Lers $\varnothing$ Parkallé, 105 DK-2100 Copenhagen, Denmark. [amm@nrcwe.dk] 
to cardiovascular and lung diseases, including cancer of the lung $(10,11)$. A major source of particulate air pollution is the combustion of fossil fuels such as diesel fuel. It was recently found that combustion particles from an incineration plant in Denmark were genotoxic and induced inflammation in vitro (12).

The aim of this study was to investigate whether airborne dust from a boiler room and from a straw storage hall results in inflammation and DNA (deoxyribonucleic acid) damage in exposed mice. Two types of airborne dust collected from a biofuel plant were evaluated in mice, and the microbial components and inorganic elements of the dust were characterized.

\section{Material and methods}

\section{The biofuel plant}

The biofuel plant was situated on Zealand in Denmark. The plant generated energy ( $428 \mathrm{TJ} / \mathrm{year}$ ) with straw as the fuel. There were three main work areas at the plant. The first was a combined straw-receiving and storage hall, called the "straw storage hall" in this publication. The second was a combined straw-feeding and boiler room that was present in a higher level in the building; this area is called the boiler room in this publication. The third was the offices.

\section{Sampling of large amounts of airborne dust}

A high-volume electrostatic field sampler was used to collect the dust. The sampler was used with a prefilter made of synthetic fiber. The prefilter is classified as filterclass G (Look-fair, Vicenza, Italy). It was characterized for its penetration of particles at the biofuel plant in the straw storage hall, and the particles collected in our study were respirable particles. These investigations have been reported in another paper (2). Dust was sampled for 7 days in August 2006 with two samplers in the straw storage hall and three samplers in the boiler room. The two sampling areas were chosen because people worked in these areas, and we expected the dust to contain particles from the straw, the vehicles unloading the straw, forklift trucks, and the combustion process.

The particles were extracted from sampling plates as described by Madsen \& Sharma (2). The microbial components were quantified in $2 \mathrm{ml}$ of the extract (2), and the rest was lyophilized and gently retrieved using a glass spatula and then weighed.

\section{Personal sampling and the extraction of dust}

Two persons were carrying Gesamtstaubprobenahme (GSP) samplers [CIS (conical inhalable sampler), by BGI, Waltham, MA, USA] throughout the workday
(7 hours) in August 2006. The samplers were mounted with Teflon filters (pore size $1 \mu \mathrm{m}$ ) and polycarbonate filters (pore size $0.8 \mu \mathrm{m}$ ). The flow was $3.5 \mathrm{l} / \mathrm{minute}$, and it was checked every hour. The dust on the Teflon filters was extracted in $6.0 \mathrm{ml}$ of pyrogen-free water with $0.05 \%$ Tween 20 (polyoxyethylenesorbitanmonooleate) by orbital shaking (300 revolutions/minute) at room temperature for 60 minutes and centrifuging $(1000 \mathrm{~g})$ for 15 minutes, and the endotoxin content was determined in the supernatant. The polycarbonate filters were extracted in $10.0 \mathrm{ml}$ of sterile $0.05 \%$ Tween 80 and an aqueous solution of $0.85 \%$ sodium chloride $(\mathrm{NaCl})$ by shaking for a 15 -minute period (500 rounds/minute) at room temperature.

\section{Quantification of microorganisms}

Microorganisms were quantified using a modified CAMNEA method (13). The numbers of fungi cultivable were estimated on dichloran glycerol agar (DG 18 agar, Oxoid, Basingstoke, England) at $25^{\circ} \mathrm{C}$ and $45^{\circ} \mathrm{C}$. Estimates were made of the number of bacteria cultivable at $25^{\circ} \mathrm{C}$ on nutrient agar (Oxoid, Basingstoke, England) with cycloheximide $(50 \mathrm{mg} / \mathrm{l})$ and of mesophilic actinomycetes $\left(25^{\circ} \mathrm{C}\right)$ and thermophilic actinomycetes $\left(55^{\circ} \mathrm{C}\right)$ cultivable on $10 \%$ and $100 \%$ nutrient agar with cycloheximide $(50 \mathrm{mg} / \mathrm{l})$, respectively. Microorganisms were identified by morphology studies and quantified as colony-forming units (cfu) per milligram of dust or per cubic meter of air.

The total numbers of bacterial cells and fungal spores were determined after staining in 20-ppm acridine orange (Difco, 212536, MD, USA) in acetate buffer for 30 seconds with subsequent filtration through a dark polycarbonate filter $(25 \mathrm{~mm}, 0.4 \mu \mathrm{m}$; Nuclepore, Cambridge, MA, USA). Fungi and bacteria were counted at a magnification of 1250 times using epi-fluorescence microscopy (Orthoplan; Leitz Wetzlar, GMBH Wetzlar, Germany). The number of microorganisms was determined in 40 randomly chosen fields or until at least 400 cells were counted.

\section{Quantification of endotoxins, beta-glucan and beta- glucosidase}

The supernatant was analyzed (in duplicate) for endotoxins using the kinetic limulus amboecyte lysate test (Kinetic-QCL endotoxin kit; BioWhittaker, Walkersville, MD, USA). A standard curve obtained from an Escherichia coli (O55:B5) reference endotoxin was used to determine the concentrations in terms of endotoxin units $(\mathrm{EU})(12.0 \mathrm{EU} \approx 1.0 \mathrm{ng}$ ). Dust suspensions from the polycarbonate filters were used to quantify $\beta$-glucan using the kinetic fungitic G test (Seikagaku Co, Tokyo, 
Japan). The results were expressed as nanograms per milligrams of dust.

To quantify the activity of the cellulase, $\beta$-glucosidase (EC 3.2.1.21) (at $37^{\circ} \mathrm{C}$ ) release of $p$-nitrophenol from $p$-nitro-phenol-N-acetyl- $\beta$-D-glucopyranoside (Sigma-Aldrich Chemical, Steinheim, Germany) was quantified $(14,15)$. The controls were without either the enzyme or the substrate. One unit of enzyme activity was defined as the amount of enzyme that releases $1.0 \mu \mathrm{mol}$ of $p$-nitro-phenol per milliliter of enzyme per minute.

\section{Analysis of inorganic elements}

Dust generated from straw by a rotating drum, as described by Madsen et al (3), and dust sampled by the electrostatic field sampler in the boiler room and in the straw storage hall was analyzed for inorganic elements. Inorganic elements were determined by inductively coupled plasma mass spectrometry (ICP-MS) (12). An amount of $30 \mathrm{mg}$ of dust was used for the semi-quantitative analysis of the elements.

\section{Animals}

The experiments were performed with C57BL/6J female mice (Taconic Europe Ry, Denmark). The mice were housed under controlled environmental conditions with 12-hour light-dark cycles with light starting at 0600 before the exposure. Food (Altromin no 1324, Christian Petersen, Denmark) and tap water were provided ad libitum. The mice were 9-11 weeks old at the time of the exposure.

\section{Intratracheal instillation exposure of mice}

The study consisted of two exposure experiments. In the first, single doses were given, and, in the second, multiple doses were given. The two experiments are

Table 1. Overview of the experiments of exposure to biofuel dust. The first experiment was a single-dose experiment, while the second was a multiple-dose experiment.

\begin{tabular}{lcl}
\hline Experiment & $\begin{array}{c}\text { Number } \\
\text { of } \\
\text { mice }\end{array}$ & \\
\hline First & 10 & $1 \times 0.9 \%$ sodium chloride \\
& 5 & $1 \times 18 \mu \mathrm{g}$ of dust from boiler room \\
& 5 & $1 \times 54 \mu \mathrm{g}$ of dust from boiler room \\
& 5 & $1 \times 18 \mu \mathrm{g}$ of dust from straw storage hall \\
& 5 & $1 \times 54 \mu \mathrm{g}$ of dust from straw storage hall \\
Second & 15 & $4 \times 0.9 \%$ sodium chloride \\
& 15 & $4 \times 54 \mu \mathrm{g}$ of dust from boiler room \\
& 15 & $4 \times 54 \mu \mathrm{g}$ of dust from straw storage hall \\
\hline
\end{tabular}

described in table 1 . The amount of $1 \mathrm{mg}$ of dust was suspended in $1 \mathrm{ml}$ of $0.9 \% \mathrm{NaCl}$ and sonicated. Before the exposure, the mice were anesthetized with a mixture of $1.5 \mathrm{mg} / \mathrm{kg}$ Hypnorm [fentanyl citrate $(0.315 \mathrm{mg} / \mathrm{ml})$ and fluanisone $(10 \mathrm{mg} / \mathrm{ml})$ from Janssen VetaPharma, Ltd, Leeds, UK] and $1.5 \mathrm{mg} / \mathrm{kg}$ Dormicum [Midazolam (5 mg/ml) from Roche a/s, Hvidovre, Denmark].

The mice were given one intratracheal instillation (18 $\mu \mathrm{g}$ or $54 \mu \mathrm{g}$ of dust suspended in $40 \mu \mathrm{l}$ of saline) or four instillations with $54 \mu \mathrm{g}$ of dust, each on four consecutive days. The mice were killed with pentobarbital 1 hour after the last exposure. Their organs were removed and snap frozen in cryotubes in liquid nitrogen and stored at $-80^{\circ} \mathrm{C}$. When we gave the mice four doses, the mice received a total of $216 \mu \mathrm{g}$ of dust (which corresponded to $10.8 \mu \mathrm{g} / \mathrm{g}$ of body weight if the mouse weighed $20 \mathrm{~g}$ ). One instillation of $54 \mu \mathrm{g}$ of dust corresponded to the endotoxin inhaled during 3 days in the biofuel plant, and four doses of $54 \mu \mathrm{g}$ corresponded to 2 weeks of inhalation (see the Discussion section). Furthermore, the multiple doses corresponded to doses of carbon black known to cause DNA damage (16).

\section{Interleukin-6, macrophage inflammatory protein-2, and monocyte chemoattractant protein-1, messenger ribonucleic acid expression in lung tissue}

RNA (ribonucleic acid) was purified from the left lung (SV Total RNA Isolation System, Promega, Birkerød, Denmark) as described by the manufacturer. It was treated with deoxyribonuclease (Dnase), and cDNA (complementary DNA) was prepared from RNA using TaqMan reverse transcription reagents from Applied Biosystems (Foster City, CA, USA). TaqMan predeveloped reaction kits from Applied Biosystems were applied for the realtime polymerase chain reaction (PCR) of interleukin-6 (IL-6), monocyte chemoattractant protein-1 (MCP-1), and $18 \mathrm{~S}$ rRNA (18S ribosomal RNA). For the realtime PCR of macrophage inflammatory protein-2 (MIP-2), probes and primers were designed as previously described by Chiu et al (17). Primers were delivered from TAG Copenhagen, and the probes came from Applied Biosystems. In all of the PCR, TaqMan universal PCR master mix from Applied Biosystems was used. The realtime PCR of the target gene and 18S rRNA was run simultaneously for each sample. Each sample was run in triplicate on the ABI Prism 7300 sequence detector system (PE Biosystems, Foster City, CA, USA). The target genes were normalized to 18S rRNA expression, and the relative gene expression of the target gene was calculated by the comparative method $2^{-\Delta \mathrm{Ct}}(18)$.

The average standard deviation of the triplicates was below $15 \%$. The standard deviation of repeated measurements of the same sample (the control) in separate experiments was $30 \%$, indicating the day-to-day 
variation of the assay. Negative controls, in which RNA was not converted to cDNA, were included in each run. In the validation experiments, the PCR was shown to be quantitative over a wide range of cDNA concentrations. If the $\mathrm{C}_{\mathrm{t}}$ (cycle threshold value) of $18 \mathrm{~S}$ fell outside the range in which the PCR had been found to be quantitative, the measurements were excluded.

\section{Bronchoalveolar lavage}

The cellular composition of the samples of bronchoalveolar lavage (BAL) fluid was determined by flushing $0.9 \%$ sterile $\mathrm{NaCl}$ through the trachea of the mice three times. BAL cells were recovered by centrifugation at $4^{\circ} \mathrm{C}$ for 10 minutes at $400 \mathrm{~g}$ and resuspended in $100 \mathrm{mi}$ croliters of Ham's F-12 nutrient mixture, including 10\% fetal bovine serum. The viability and the total number of cells were estimated using Trypan blue staining. Fifty-microliter cell suspensions were centrifuged for 4 minutes at $55 \mathrm{~g}$ in a cytocentrifuge (StatSpin Cytofuge 2, Norwood, MA, USA) and fixed for a differential count on a microscope slide with $96 \%$ ethanol and stained with May-Grünwald-Giemsa reagents (Merck, VWR International, Damstadt, Germany). The cellular composition of the BAL cells was determined on 200 cells by microscopy. Macrophages, lymphocytes, neutrophils, and eosinophils were counted.

\section{Comet assay}

DNA strand breaks were determined in the BAL cells with the use of the comet assay, as described earlier (19), with minor modifications. Genotoxicity was determined by measuring strand break formation in the BAL cells for the following reasons: (i) these cells are easily obtained as a single-cell suspension from lung lavage, (ii) the BAL cells are adjacent to the epithelial cells and may be relevant surrogates, (iii) there seems to be a "dilution" effect of the strand breaks in a lung tissue homogenate, and (iv) this end point has been successfully used in our previous studies of particle-induced genotoxicity (16, 19, 20). As a control of the comet assay, untreated and hydrogen-peroxide $(30 \mu \mathrm{M}$ )-treated A549 cells (human lung epithelial cell line) were included.

\section{Statistical analysis}

An analysis of variance using SYSTAT software package version 9 (SPSS Marketing Department, Chicago, IL, USA) was applied in the evaluation of a dose-response relationship. When the data did not fulfill the requirements of a one-way analysis of variance, they were analyzed using nonparametric tests. For comparing two groups, a Mann-Whitney test was applied, and, when more than two groups were compared, a Kruskal-Wallis test was used, followed by a Mann-Whitney test. The statistical analyses were performed in MINITAB 14 (Minitab Inc, State College, PA, USA). The accepted level of significance was 0.05 .

\section{Results}

\section{Microbial and metal content of the dust samples}

The dust sampled from the straw storage hall contained more of most of the microbial components than the dust from the boiler room (table 2). The lyophilization of the dust greatly affected the cultivability of the collected fungi, and, after the lyophilization, only a minor fraction of the fungal colonies was obtained when compared with the amount before the lyophilization.

The content of inorganic elements in the dust used for the exposure of the mice is presented in table 3. For most of the inorganic elements, the concentration was greater in the dust from the straw storage hall than in the dust from the boiler room. The concentrations of the elements in the straw dust were considerably lower than in the dust from the boiler room and the straw storage hall.

\section{Human exposure at the plant}

The person working in the storage hall, who mainly drove a truck and transported straw, was exposed to the following air concentrations: $0.62 \mathrm{mg} \mathrm{dust} / \mathrm{m}^{3}$, $167 \times 10^{4}$ fungal spores $/ \mathrm{m}^{3}, 62 \times 10^{4} \mathrm{cfu}$ of fungi $/ \mathrm{m}^{3}$, $31 \mathrm{cfu}$ of Aspergilus fumigatus $/ \mathrm{m}^{3}, 394 \times 10^{4} \mathrm{bacteria} / \mathrm{m}^{3}$, $1298 \mathrm{EU} / \mathrm{m}^{3}$, and 626 and $2.1 \times 10^{4} \mathrm{cfu}$ of thermophilic and mesophilic actinomycetes $/ \mathrm{m}^{3}$, respectively. Another

Table 2. Fungal and bacterial components and $\mathrm{pH}$ of the dust samples used for the exposure of the mice. (cfu = colony-forming units, $\mathrm{BD}=$ below the detection level, EU = endotoxin units)

\begin{tabular}{lcll}
\hline Microbial component & Unit & $\begin{array}{l}\text { Boiler } \\
\text { room } \\
\text { (unit/mg dust) }\end{array}$ & $\begin{array}{l}\text { Straw } \\
\text { storage hall } \\
\text { (unit/mg dust) }\end{array}$ \\
\hline Total fungi & Number & $130 \times 10^{4}$ & $170 \times 10^{4}$ \\
Mesophilic fungi & $\mathrm{cfu}$ & 172 & 35 \\
Aspergillus fumigatus & $\mathrm{cfu}$ & $+^{\mathrm{a}}$ & $+^{\mathrm{a}}$ \\
Cladosporium herbarum & $\mathrm{cfu}$ & $+^{\mathrm{a}}$ & $+^{\mathrm{a}}$ \\
Eurotium species & $\mathrm{cfu}$ & $\mathrm{BD}$ & $+^{\mathrm{a}}$ \\
beta-Glucan & $\mathrm{ng}$ & $3.1 \times 10^{4}$ & $20 \times 10^{4}$ \\
beta-Glucosidase & Pmol/s & 0.128 & 0.129 \\
Total bacteria & Number & $58 \times 10^{4}$ & $84 \times 10^{4}$ \\
Mesophilic bacteria & $\mathrm{cfu}$ & 1063 & 5231 \\
Endotoxin & $\mathrm{EU}{ }^{\mathrm{b}}$ & 196 & 286 \\
Mesophilc actinomycetes & $\mathrm{cfu}$ & 35 & $1.7 \times 10^{4}$ \\
Thermophilic actinomycetes & $\mathrm{cfu}$ & $20 \times 10^{4}$ & $6.9 \times 10^{4}$ \\
pH & & 7.19 & 7.10 \\
\hline
\end{tabular}

a Cultivable from the sample before lyophilization but not after.

b $12.0 \mathrm{EU} \approx 1.0 \mathrm{ng}$. 
Table 3. Concentrations of inorganic elements in the dust samples used for the exposure of mice and for the comparison with the straw dust samples.

\begin{tabular}{|c|c|c|c|c|}
\hline \multirow[t]{2}{*}{ Element } & \multirow[t]{2}{*}{$\begin{array}{c}\text { Boiler room } \\
\text { dust }(p p m)(N=1)\end{array}$} & \multirow[t]{2}{*}{$\begin{array}{l}\text { Straw storage hall } \\
\text { dust }(\mathrm{ppm})(\mathrm{N}=1)\end{array}$} & \multicolumn{2}{|c|}{$\begin{array}{l}\text { Straw dust } \\
(\mathrm{ppm})(\mathrm{N}=3)\end{array}$} \\
\hline & & & Mean & SD \\
\hline Calcium & 53061 & 120068 & 11893 & 1714 \\
\hline Potassim & 303154 & 39166 & 5114 & 473 \\
\hline Sodium & 44266 & 29817 & 246 & 72 \\
\hline Aluminium & 6789 & 30275 & 1510 & 810 \\
\hline Magnesium & 5892 & 8684 & 1801 & 209 \\
\hline Iron & 16434 & 49147 & 1825 & 757 \\
\hline Manganese & 361 & 1014 & 149 & 38 \\
\hline Phosphorus & 1890 & 3230 & 1198 & 98 \\
\hline Zinc & 1770 & 3077 & 60 & 8 \\
\hline Nickel & 568 & 203 & 6 & 4 \\
\hline Copper & 530 & 1062 & 10 & 2 \\
\hline Lead & 127 & 455 & 6 & 2 \\
\hline Chromium & 38 & 108 & 10 & 4 \\
\hline Cadmium & 5 & 6 & . & . \\
\hline
\end{tabular}

person, who worked in the boiler room with bottom ash, cleaned the straw storage hall and worked in the office, was exposed to the following air concentrations: $1.18 \mathrm{mg}$ dust $/ \mathrm{m}^{3}, 215 \times 10^{4}$ fungal spores $/ \mathrm{m}^{3}$, $1.7 \times 10^{4} \mathrm{cfu}$ of fungi $/ \mathrm{m}^{3}, 92 \mathrm{cfu}$ of A fumigatus $/ \mathrm{m}^{3}$, $1116 \times 10^{4}$ bacteria $/ \mathrm{m}^{3}, 2178 \mathrm{EU} / \mathrm{m}^{3}, 6184 \mathrm{cfu}$ of mesophilic actinomycetes $/ \mathrm{m}^{3}$, and to below the detection level of thermophilic actinomycetes.

\section{Effects of the exposure of mice}

DNA damage-single dose. No difference in the extent of DNA damage in BAL cells was found between each of the two groups of mice exposed to dust and the control group (results not shown).

$B A L$ cells - single dose. No statistically significant effect on total cell number or the BAL cell composition was observed for the mice exposed to a single dose of dust from the boiler room or a single dose of dust from the straw storage hall in a comparison with the control mice (table 4). However, the total cell number was reduced nonsignificantly in the mice exposed to dust from the straw storage hall when compared with that of the control mice. There was no difference in the cell viability measured by trypan blue staining between the control and dust-exposed mice, and the cell viability exceeded $95 \%$ in all of the cases (results not shown).

Quantitative polymerase chain reaction of cytokinessingle dose. Exposure to dust from the boiler room did not result in any increase in IL-6, MCP-1 or MIP-2 mRNA (messenger RNA) expression when compared with the control situation. Exposure to dust from the straw storage hall increased the mRNA expression of IL-6. There was a dose-response relationship between the IL-6 mRNA expression and the amount of dust from the straw storage hall $(\mathrm{P}=0.039)$. After exposure to $54 \mu \mathrm{g}$ of dust from the straw storage hall, the IL-6 (figure 1) and MIP-2 (figure 2) mRNA expression was significantly increased $(\mathrm{P}<0.05$ and $\mathrm{P}<0.01$, respectively) when compared with the control situation, whereas the MCP-1 expression remained unchanged (figure 3 ).

DNA damage-multiple doses. The extent of the DNA damage in BAL cells was found to be similar in the

Table 4. Cellular profile for the bronchoalveolar lavage fluid after the intratracheal instillation of dust from the boiler room or the straw storage hall.

\begin{tabular}{|c|c|c|c|c|c|c|c|c|c|c|c|c|}
\hline \multirow[t]{2}{*}{ Exposure } & \multirow[t]{2}{*}{$\begin{array}{l}\text { Dose } \\
(\mu g)\end{array}$} & \multirow[t]{2}{*}{$\begin{array}{l}\text { Animals } \\
(\mathrm{N})\end{array}$} & \multicolumn{2}{|c|}{$\begin{array}{c}\text { Total cells } \\
\left(\times 10^{4}\right)\end{array}$} & \multicolumn{2}{|c|}{$\begin{array}{l}\text { Macrophages } \\
\quad\left(\times 10^{4}\right)\end{array}$} & \multicolumn{2}{|c|}{$\begin{array}{l}\text { Neutrophils } \\
\left(\times 10^{4}\right)\end{array}$} & \multicolumn{2}{|c|}{$\begin{array}{l}\text { Lymphocytes } \\
\qquad\left(\times 10^{4}\right)\end{array}$} & \multicolumn{2}{|c|}{$\begin{array}{l}\text { Eosinophils } \\
\qquad\left(\times 10^{4}\right)\end{array}$} \\
\hline & & & Mean ${ }^{a}$ & $\mathrm{SD}^{\mathrm{a}}$ & Mean ${ }^{a}$ & $S D^{a}$ & Mean ${ }^{a}$ & $\mathrm{SD}^{\mathrm{a}}$ & Mean ${ }^{a}$ & $S D^{a}$ & Mean ${ }^{a}$ & $\mathrm{SD}^{\mathrm{a}}$ \\
\hline \multicolumn{13}{|l|}{ Single dose exposure } \\
\hline $0.9 \%$ sodium chloride & $1 \times 0$ & 9 & 12 & 1.5 & 12 & 3.5 & 0.13 & 0.18 & 0.17 & 0.07 & 0.007 & 0.02 \\
\hline Boiler room dust & $1 \times 18$ & 5 & 9.1 & 3.1 & 8.8 & 3.1 & 0.13 & 0.10 & 0.13 & 0.07 & 0 & \\
\hline Boiler room dust & $1 \times 54$ & 5 & 10 & 6.6 & 9.9 & 6.5 & 0.05 & 0.04 & 0.13 & 0.07 & 0 & \\
\hline Straw storage hall dust & $1 \times 18$ & 4 & 4.8 & 2.4 & 4.7 & 2.3 & 0.04 & 0.02 & 0.099 & 0.06 & 0.004 & 0.009 \\
\hline Straw storage hall dust & $1 \times 54$ & 4 & 3.9 & 1.3 & 3.7 & 1.3 & 0.03 & 0.03 & 0.13 & 0.03 & 0 & \\
\hline \multicolumn{13}{|l|}{ Repeated exposures } \\
\hline $0.9 \%$ sodium chloride & $4 \times 0$ & 13 & 11 & 18.4 & 5.3 & 3.5 & 4.7 & 14.2 & 0.40 & 0.97 & 0.02 & 0.02 \\
\hline Boiler room dust & $4 \times 54$ & 14 & $29 b$ & 11.1 & 6.7 & 3.0 & $18^{c}$ & 11.1 & $2.6^{d}$ & 1.7 & $1.2^{c}$ & 2.2 \\
\hline Straw storage hall dust & $4 \times 54$ & 14 & $35^{b}$ & 16.4 & 6.8 & 2.8 & $21^{c}$ & 10.6 & $5.0^{c}$ & 3.2 & $1.9^{b}$ & 2.4 \\
\hline
\end{tabular}

a Total numbers in lavage fluid $(3 \mathrm{ml})$ is shown.

b $P<0.01$ versus control mice.

c $P<0.001$ versus control mice.

d $\mathrm{P}<0.05$ versus control mice. 

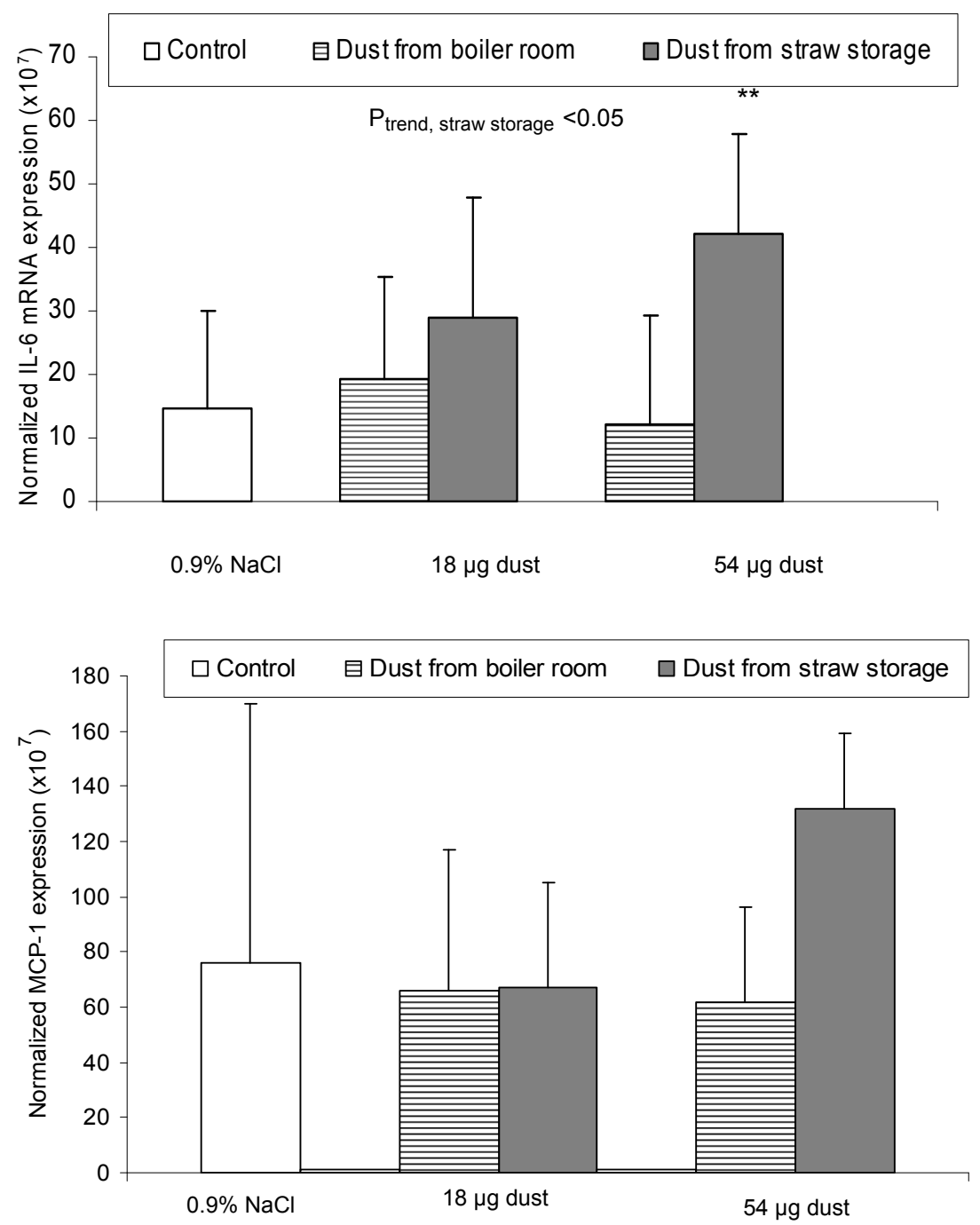

Figure 1. Expression level of interleukin-6 (IL-6) mRNA (messenger ribonucleic acid) in the C57BL/6J mouse lungs 1 hour after a single exposure to different amounts of dust from the boiler room $(\mathrm{N}=4)$ or straw storage hall $(\mathrm{N}=4)$. To the control mice $(\mathrm{N}=9), 0.9 \%$ sodium chloride $(\mathrm{NaCl})$ without dust was instilled. The mRNA levels were quantified by realtime polymerase chain reaction (RT-PCR) and normalized to $18 \mathrm{~S}$ rRNA (18S ribosomal ribonucleic acid). $\left({ }^{*}\right.$ Significantly greater than the control sample, $\mathrm{P} \leq 0.01$ )

Figure 2. Expression level of monocyte chemoattractant protein-1 (MCP-1) mRNA (messenger ribonucleic acid) in the C57BL/6J mouse lungs 1 hour after a single exposure to different amounts of dust from the boiler room $(\mathrm{N}=4)$ or straw storage hall $(\mathrm{N}=4)$. To the control mice $(\mathrm{N}=9), 0.9 \%$ sodiurm chloride $(\mathrm{NaCl})$ without dust was instilled. The mRNA levels were quantified by realtime polymerase chain reaction (RTPCR) and normalized to 18S rRNA (18S ribosomal ribonucleic acid).

Figure 3. Expression level of macrophage inflammatory protein-2 (MIP-2) mRNA (messenger ribonucleic acid) in the C57BL/6J mouse lungs 1 hour after a single exposure to different amounts of dust from the boiler room $(\mathrm{N}=4)$ or straw storage hall $(\mathrm{N}=4)$. To the control mice $(\mathrm{N}=9) \quad 0.9 \%$ sodium chloride $(\mathrm{NaCl})$ without dust was instilled. The mRNA levels were quantified by realtime polymerase chain reaction and normalized to $18 \mathrm{~S}$ rRNA (18S ribosomal ribonucleic acid). ( ${ }^{* *}$ Significantly greater than the control sample, $P \leq 0.01$ )

dust-exposed groups and the control group (figure 4). Thus exposure to high levels of dust from the biofuel plant was not DNA damaging.
$B A L$ cells-multiple doses. The repeated dust exposure induced significant increases in the total number of cells, lymphocytes, neutrophils, and eosinophils as compared 

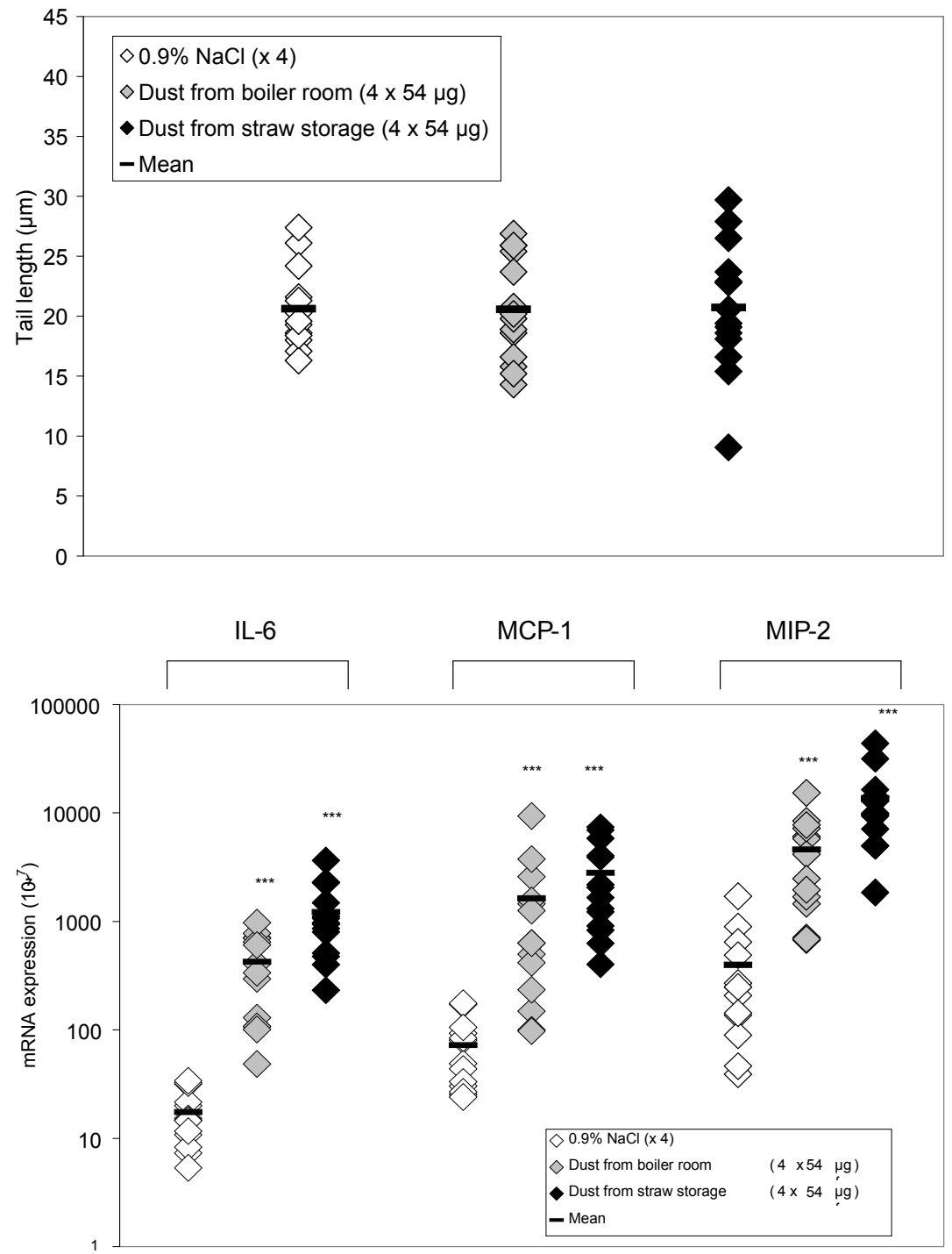

Figure 4. Effect of dust from the boiler room and straw storage hall on the formation of DNA (deoxyribonucleic acid) strand breaks was evaluated by the comet assay $(\mathrm{N}=13-14)$.

Figure 5. Expression levels of mRNA (messenger ribonucleic acid) for interleukin-6 (IL-6), monocyte chemoattractant protein-1 (MCP-1), and macrophage inflammatory protein-2 (MIP-2) in the C57BL/6J mouse lungs $1 \mathrm{hour}$ after the last exposure $(\mathrm{N}=13-14)$ to biofuel dust. The mRNA levels were quantified by realtime polymerase chain reaction and normalized to $18 \mathrm{~S}$ rRNA (18S ribosomal ribonucleic acid). $\left({ }^{* *}\right.$ Significantly greater than the control, $\mathrm{P} \leq 0.0001)$ with the exposure to $0.9 \% \mathrm{NaCl}$; this finding indicates an inflammatory response (table 4). One hour after the last dose, the total cell numbers increased 3.3 times in the mice exposed to dust from the boiler room and 2.8 times in those exposed to dust from the straw storage hall when compared with the levels in the control mice ( $\mathrm{P}<0.01$ for both groups). The increase in the total cell number was the result of significant increases in the fractions of neutrophilic granulocytes, lymphocytes, and eosinophils. There was no difference in cell viability between the controls and the dust-exposed mice, and the viability exceeded $97 \%$ in all of the cases (results not shown).

Quantitative polymerase chain reaction of cytokinesmultiple doses. The average mRNA expression levels of IL-6 and MCP-1 were more than 20 times greater in the mice exposed to dust from the boiler room and more than 10 times greater for MIP-2 when compared with the levels of the control group (figure 5). Exposure to dust from the straw storage hall increased the mRNA expression levels even more, the IL- 6 mRNA expression level being 60 times greater and the MCP-1 and MIP-2 mRNA being more than 30 times greater than in the control group $(\mathrm{P} \leq 0.0001)$. The mRNA expression levels of the mice exposed to the dust from the straw storage hall were statistically significantly higher for IL-6 and MIP-2 $(\mathrm{P}<0.01)$ than that of the mice exposed to the boiler room dust, but only marginally greater for MCP-1 $(\mathrm{P}=0.051)$. Thus the exposure to dust from the biofuel plant resulted in a major inflammatory response in the lungs of the exposed mice.

\section{Discussion}

Exposure of mice to multiple doses of airborne dust from a biofuel plant converting straw induced substantial 
pulmonary inflammation, including neutrophil infiltration and increased cytokine expression in the lungs of the mice. The mice exposed to a single dose only responded significantly after exposure to the highest dose of dust from the straw storage hall. No increase in DNA-damaging effects in BAL cells was detected at the studied points in time after either single or multiple exposures to both types of dust. Exposure to dust from the straw storage hall caused a more than 60 -fold increase in IL-6 mRNA expression. In a study with the inhalation of carbon black, at doses corresponding to the multiple doses in this study, only a threefold increase in IL-6 mRNA expression was found, even though increased DNA damage was detected (16). It is interesting to note from this study that a strong inflammatory response does not necessarily induce genotoxic effects in BAL cells because in vitro studies have shown that genotoxicity can be mediated by a particle-induced inflammatory response (21). In accordance with this study, a similar in vitro study with wood dust showed that the dust was genotoxic, without an induced inflammatory response (22).

To our knowledge, the genotoxic and inflammatory effects of dust from biofuel plants have not been evaluated previously. However, some studies have evaluated the effects of exposure to, for example, endotoxins and other types of organic dust $(23,24)$. The inflammatory effect of the biofuel dust may be caused by the high concentrations of microorganisms and endotoxins in the dust. The exposure of mice to endotoxins in this study corresponds in the single dose of $18 \mu \mathrm{g}$ of dust from the straw storage hall to $0.021 \mu \mathrm{g}$ endotoxin $/ \mathrm{kg}$ mouse (if the mouse weighed $20 \mathrm{~g}$ ). In the multiple doses with a total dust amount of $216 \mathrm{mg}$, this corresponds to 0.257 $\mathrm{mg}$ endotoxin $/ \mathrm{kg}$ mouse. In an inhalation study with humans, in which inflammatory responses were found, the participants were exposed to higher concentrations of endotoxins than those used in this study. Thus the participants were exposed to $0.1 \mathrm{ml}$ inhalant $/ \mathrm{kg}$ body weight with $0.9 \mu \mathrm{g}$ or $6.0 \mu \mathrm{g}$ endotoxins/ml inhalant (25, 26), corresponding to $0.09-0.6 \mathrm{mg}$ endotoxins/ $\mathrm{kg}$ body weight. The dust used in our study also contained spores of fungi and actinomycetes and the strong inflammatory response to the dust exposure may have been caused by the composition of different microbial components. Thus synergistic effects on the induction of inflammation are found for endotoxin and organic dust particles (27), and the fungus Metarhizium anisopliae has been found to have an adjuvant effect on the allergic response to ovalbumin in mice (28).

In this study, we chose to evaluate genotoxic and inflammatory effects 1 hour after instillations of dust because our previous studies have shown that genotoxicity occurs before the recruitment of neutrophils. Thus in vivo studies have shown genotoxicity 1 hour after ozone exposure of mice (20), and in vitro studies with human epithelial cells have shown DNA damage and no inflammation after 3 hours of wood-dust exposure (22). Furthermore, in both studies, the DNA damage was repaired after 3 and 6 hours, respectively, underlining the importance of early measurements of DNA damage. Consequently, it is important to study DNA damage early after exposure. Inflammatory end points, such as the recruitment of neutrophils, are generally maximal after 18-24 hours. Particle-induced genotoxicity can be considered to occur in two different ways, referred to as primary and secondary genotoxicity. Primary genotoxicity is defined as genetic damage caused by particles in the absence of pulmonary inflammation, whereas secondary genotoxicity implies a pathway of genetic damage that results from the oxidative DNA attack by reactive oxygen or nitrogen species (ROS/RNS), generated during particle-induced inflammation (29). To study primary, as well as secondary, effects of dust, we designed our study set-up to detect primary genotoxicity 1 hour after a single instillation of dust, while secondary genotoxic effects caused by inflammation would be detected in mice exposed to four consecutive doses of dust.

The single-dose exposure showed that the dust from the straw storage hall induced a dose-dependent mRNA expression of IL-6. This finding was further validated by the multiple-dose exposure, during which IL-6 mRNA expression increased even further. A dose-dependent response of IL-6 mRNA expression has previously been observed in mice after the inhalation of diesel exhaust particles (19). In this study, cytokine expression was evaluated 1 hour after instillation. The time point was chosen as optimal for the detection of DNA damage. A later time point may have been more optimal for the detection of an eosinophil infiltration of the lungs and for IL-6 expression.

Surprisingly, a single exposure to straw dust reduced the number of inflammatory cells in BAL fluid 1 hour after the exposure. However, similar effects have previously been shown for humans exposed to other air pollutants, such as ozone (30) and hydrogen fluoride (31). An explanation for such a decrease in BAL-cell number after an exposure could be cytotoxicity, but in this study no effect on BAL-cell viability was detected.

The concentration of total fungi in the dust sampled by the electrostatic samplers was at the same level as that in the total dust from straw in another study (3). In contrast, the concentrations of endotoxins and total bacteria were lower than in the total straw dust in the other study. This difference is probably due to the fact that the large fractions of bacteria and endotoxins are not present as respirable particles, as seen in other studies $(2,32)$. The two dust samples from the boiler room and the straw storage hall also contained high concentrations of fungi, bacteria, and endotoxins in comparison with, 
for example, dust generated from composting household waste (33). The highest concentrations of most microbial components were found in the dust from the straw storage hall. In the straw storage hall, large amounts of straw were handled before being transported to the boiler room.

In accordance with another study (1), the measurements of individual persons revealed high exposure levels for two persons working in the plant. There are no internationally accepted threshold limit values for endotoxins. In the literature, suggested values range between 30 and $800 \mathrm{EU} / \mathrm{m}^{3}(1)$, and outdoor reference measurements are around $1.3 \mathrm{EU} / \mathrm{m}^{3}$ (34). Thus the endotoxin exposure of more than $1200 \mathrm{EU} / \mathrm{m}^{3}$ found at the plant must be considered high. The exposure to fungi was also high when compared with the fungal exposure levels reported to be associated with the development of respiratory symptoms in agricultural environments (6). The exposure to inhalable dust was lower than the Danish occupational exposure limit of $3 \mathrm{mg} / \mathrm{m}^{3}$ for total organic dust (35).

When mice were instilled with dust four times, the total dose was $216 \mu \mathrm{g}$ of dust. This level corresponds to $10.8 \mu \mathrm{g} / \mathrm{g}$ body weight (if a mouse weighs $20 \mathrm{~g}$ ). The $216 \mu \mathrm{g}$ of dust from the boiler room dust contained $42 \mathrm{EU}$, which is $2.1 \mathrm{EU} / \mathrm{g}$ body weight of the mouse. This level corresponds to about 2 weeks of exposure for the two persons working at the plant (assuming an employee weighs $70 \mathrm{~kg}$, inhales $8 \mathrm{~m}^{3}$ of air during a workday, and works 5 days a week). Although an exact extrapolation from mouse to man is difficult, the chosen experimental doses are realistic when compared with the occupational exposure concentrations. This comparison strongly indicates that exposure to realistic concentrations of biofuel aerosols elicits a strong inflammatory response without inducing DNA damage. However, more data are needed for an understanding of how the data should be interpreted in a comprehensive risk assessment of exposure at biofuel plants.

The concentrations of most of the inorganic elements were higher in the dust from the straw storage hall than in the boiler-room dust. This finding indicates that the inorganic compounds originated from emission sources other than the combustion process in the boiler room. High levels of iron, manganese, copper, and lead are typical for traffic sources (36) and may be due to motor vehicles entering the straw storage hall to deliver straw. In addition, long-range transported particulate matter or soil dust may have influenced the dust in the straw storage hall because the gates to the hall were mostly open during workdays. The concentrations of the elements lead, cadmium, and nickel in the straw dust were negligible.

In conclusion, the instillation of the multiple-dust doses, corresponding to about 2 weeks of endotoxin exposure for a person working in the biofuel plant, caused a strong inflammatory response. The inflammatory response resulted in no detectable DNA damage in BAL cells; this finding suggests that inflammation and DNA damage are not necessarily causally linked. This finding underlines the importance of obtaining more knowledge about the relationship between particle-induced inflammation and genotoxicity. The dust collected in the straw storage hall induced a stronger inflammatory response than the dust from the boiler room and had a higher concentration of most microbial components. This finding indicates the involvement of microbial components, for example, endotoxin, in the inflammatory response. This very strong inflammatory response to the dust emphasizes the importance of studying the effects of field samples from occupational environments. We think that, for future research, it would be interesting to investigate which inorganic and organic, microbial, or other components contribute to the strong inflammatory response that was detected. In addition, the relationship between the biofuel dust exposures and respiratory symptoms such as asthma could be elucidated.

\section{Acknowledgments}

Special thanks go to Signe H Nielsen, Hediye Avci, Pernille Salvarli, Tina T Olsen, Anne-Karin Jensen, and Gitte B Kristiansen for their expert technical assistance. Extra thanks go to Jørgen Kystol at GEUS for performing the ICP-MS analysis.

We are also grateful to PSO-Eltra (5786) for its financial support.

\section{References}

1. Madsen AM. Exposure to airborne microbial components in autumn and spring during work at Danish biofuel plants. Ann Occup Hyg. 2006;50:821-31.

2. Madsen AM, Sharma AK. Sampling of high amounts of bioaerosols using a high-volume electrostatic field sampler. Ann Occup Hyg. 2008;52:167-76.

3. Madsen AM, Mårtensson L, Schneider T, Larsson L. Microbial dustiness and particle release of different biofuels. Ann Occup Hyg. 2004;48:327-38.

4. Sebastian A, Madsen AM, Mårtensson L, Pomorska D, Larsson L. Assessment of microbial exposure risks from handling of biofuel wood chips and straw-effect of outdoor storage. Ann Agric Environ Med. 2006;13:139-45.

5. Viet SM, Buchan R, Stallones L. Acute respiratory effects and endotoxin exposure during wheat harvest in Northeastern Colorado. Appl Occup Environ Hyg. 2001;16:685-97.

6. Eduard W, Douwes J, Mehl R, Heederik D, Melbostad E. Short term exposure to airborne microbial agents during farm work: exposure-response relations with eye and respiratory 
symptoms. Occup Environ Med. 2001;58:113-8.

7. Kokkarinen J, Tukiainen H, Terho EO. Severe farmer's lung following a workplace challenge [case study]. Scand J Work Environ Health. 1992;18:327-8.

8. Mandryk J, Alwis KU, Hocking AD. Effects of peronal exposures on pulmonary function and work-related symptoms among sawmill workers. Ann Occup Hyg. 2000;44:281-9.

9. Losada E, Hinojosa M, Moneo I, Dominguez J, Diez Gomez ML, Ibanez MD. Occupational asthma caused by cellulase. J Allergy Clin Immunol. 1986;77:635-9.

10. Pope CA, Burnett RT, Thun MJ, Calle EE, Krewski D, Ito $\mathrm{K}$, et al. Lung cancer, cardiopulmonary mortality, and long-term exposure to fine particulate air pollution . JAMA. 2002;287:1132-41.

11. Brunekreef B, Holgate ST. Air pollution and health. Lancet. 2002;360:1233-42.

12. Sharma AK, Jensen KA, Rank J, White PA, Lundstedt S, Gagne R, et al. Genotoxicity, inflammation and physicochemical properties of fine particle samples from an incineration energy plant and urban air. Mutat Res. 2007;633:95-111.

13. Palmgren U, Ström G, Blomquist G, Malmberg P. Collection of airborne micro-organisms on Nuclepore filters, estimation and analysis-CAMNEA method. J Appl Bacteriol. 1986;61:4016.

14. Madsen AM. NAGase activity in airborne biomass dust and relationship between NAGase concentrations and fungal spores. Aerobiologia. 2003;19:97-105.

15. Lama L, Calanfrelli V, Gambacorta A, Nicolaus B. Purification and characterization of the thermostable xylanase and $\beta$-xylosidase by the thermophilic bacterium Bacillus thermantarcticus. Res Microbiol. 2004;155:283-9.

16. Saber AT, Bornholdt J, Dybdahl M, Sharma AK, Loft S, Vogel $\mathrm{U}$, et al. Tumor necrosis factor is not required for particle-induced genotoxicity and pulmonary inflammation. Arch Toxicol. 2005;79:177-182.

17. Chiu BC, Shang X, Frait KA, Hu JS, Komuniecki E, Miller RA, et al. Differential effects of ageing on cytokine and chemokine responses during type-1 (mycobacterial) and type-2 (schistosomal) pulmonary granulomatous inflammation in mice. Mech Ageing Dev. 2002;123:313-26.

18. Livak KJ, Schmittgen TD. Analysis of relative gene expression data using real-time quantitative PCR and the 2(-Delta Delta C(T)) Method. Methods. 2001;25:402-8.

19. Dybdahl M, Risom L, Bornholdt J, Autrup H, Loft S, Wallin H. Inflammatory and genotoxic effects of diesel particles in vitro and in vivo. Mutat Res. 2004;562:119-31.

20. Bornholdt J, Dybdahl M, Vogel U, Hansen M, Loft S, Wallin $\mathrm{H}$. Inhalation of ozone induces DNA strand breaks and inflammation in mice. Mutat Res. 2002;26:63-71.

21. Knaapen AM, Güngör N, Schins RPF, Borm PJA, Van Schooten FJ. Neutrophils and respiratory tract DNA damage and mutagenesis: a review. Mutagenesis. 2006;21:225-36.

22. Bornholdt J, Saber AT, Sharma AK, Savolainen K, Vogel U, Wallin H. Inflammatory response and genotoxicity of seven wood dusts in the human epithelial cell line A549. Mutat Res.
2007;632:78-88.

23. Mättää J, Lehto M, Leino M, Tillander S, Haapakoski R, Majuri ML, et al. Machanisms of particle-induced pulmonary inflammation in a mouse model: exposure to wood dust. Toxicol Sci. 2004;93:96-104.

24. Israël-Assayag E, Cormier Y. Adaptation to organic dust exposure: a potential role of L-selectin shedding? Eur Respir J. 2002;19:833-7.

25. Jagielo PJ, Thorne PS, Watt JL, Frees KL, Quinn TJ, Schwartz DA. Grain dust and endotoxin inhalation challenges produce similar inflammatory responses in normal subjects. Chest. 1996;110:263-70.

26. Jagielo PJ, Thorne PS, Watt JL, Frees KL, Quinn TJ, Schwartz DA. Grain dust and endotoxin inhalation challenges produce similar inflammatory responses in normal subjects. Chest. 1996;110:263-70.

27. Pirie RS, Collie PM, Dixon PM, McGorum BC. Inhaled endotoxin and organic dust particulates have synergistic proinflammatory effects in equine heaves (organic dust-induced asthma). Clin Exp Allergy. 2003;33:676-83.

28. Instanes $\mathrm{C}$, Ward MD, Hetland G. The fungal biopesticide Metarhizium anisopliae has an adjuvant effect on the allergic response to ovalbumin in mice. Toxicol Lett. 2006;161:219 25.

29. Schins RP, Knaapen AM. Genotoxicity of poorly soluble particles. Inhal Toxicol. 2007;19:189-98.

30. Devlin RB, McDonnell WF, Becker S, Madden MC, McGee MP, Perez R, et al. Time-dependent changes of inflammatory mediators in the lungs of humans exposed to $0.4 \mathrm{ppm}$ ozone for $2 \mathrm{hr}$ : a comparison of mediators found in bronchoalveolar lavage fluid 1 and $18 \mathrm{hr}$ after exposure. Toxicol Appl Pharmacol. 1996;138:176-85.

31. Lund K, Dunster C, Sandström T, Kelly FJ, Søstrand P, Schwarze P, et al. Inflammatory markers in bronchoalveolar lavage fluid from human volunteers 2 hours after hydrogen fluoride exposure. Hum Exp Toxicol. 2005;24:101-8.

32. Madsen AM, Sharma AK. Sampling of high amounts of bioaerosols using a high-volume electrostatic field sampler. Ann Occup Hyg. 2007;

33. Nielsen BH, Würtz H, Breum NO, Poulsen OM. Microorganisms and endotoxin in experimentally generated bioaerosols from composting household waste. Ann Agric Environ Med. 1997;4:159-68.

34. Madsen AM. Airborne endotoxin in different background environments and seasons. Ann Agric Environ Med. 2006;13:816.

35. Arbejdstilsynet. At-vejledning. Grænseværdier for stoffer og materialer [The Danish working authority. work place exposure limits]. Copenhagen: Arbejdstilsynet; 2007. p 1-85.

36. Wåhlin P, Berkowicz R, Palmgren F. Characterisation of traffic-generated particulate matter in Copenhagen. Atmos Environ. 2006;40:2151-9.

Received for publication: 20 November 2007 